\title{
Antimutagenic activity of cashew apple (Anacardium occidentale Sapindales, Anacardiaceae) fresh juice and processed juice (cajuína) against methyl methanesulfonate, 4-nitroquinoline $\mathrm{N}$-oxide and benzo[a]pyrene
}

\author{
Ana Amelia Melo-Cavalcante ${ }^{1,2}$, Jaqueline N. Picada ${ }^{2,3}$, Gabriel Rubensam ${ }^{2}$ and João A.P. Henriques ${ }^{2,3,4}$ \\ ${ }^{1}$ Universidade Federal do Piaui, Teresina, PI, Brazil. \\ ${ }^{2}$ Laboratório de Toxicologia Genética, Centro de Biotecnologia, \\ Universidade Federal do Rio Grande do Sul, Porto Alegre, RS, Brazil. \\ ${ }^{3}$ Laboratório de Genética Toxicológica, Universidade Luterana do Brazil, Canoas, RS, Brazil. \\ ${ }^{4}$ Instituto de Biotecnologia, Universidade de Caxias do Sul, Caxias do Sul, RS, Brazil.
}

\begin{abstract}
Cashew apple juice (CAJ), produced from the native Brazilian cashew tree (Anacardium occidentale), and has been reported to have antibacterial, antifungal, antitumor, antioxidant and antimutagenic properties. Both the fresh unprocessed juice and the processed juice (cajuína in Portuguese) has been shown to consist of a complex mixture containing high concentrations of anacardic and ascorbic acids plus several carotenoids, phenolic compounds and metals. We assessed both types of juice for their antimutagenic properties against the direct mutagens methyl methanesulfonate (MMS) and 4-nitroquinoline-N-oxide (4-NQO) and the indirect mutagen benzo[a]pyrene (BaP) using pre-treatment, co-treatment and post-treatment assays with Salmonella typhimurium strains TA100, TA102, and TA97a. In pre-treatment experiments with strains TA100 and TA102 the fresh juice showed high antimutagenic activity against MMS but, conversely, co-treatment with both juices enhanced MMS mutagenicity and there was an indication of toxicity in the post-treatment regime. In pre-, co-, and post-treatments with TA97a as test strain, antimutagenic effects were also observed against 4-NQO and BaP. These results suggest that both fresh and processed CAJ can protect the cells against mutagenesis induced by direct and indirect mutagens.
\end{abstract}

Key words: antimutagenicity; BaP, cajuina, MMS, 4-NQO, Salmonella microsome assay.

Received: September 26, 2007; Accepted: March 4, 2008.

\section{Introduction}

It has been reported that some chemical components of fruit and vegetables provide protection against a series of degenerative diseases in humans, such as cancer, cardiovascular diseases, cataracts and brain dysfunction (Ames, 2001; Cambie and Ferguson, 2003). The identification of antimutagenic compounds and the evaluation of their mode of action are extremely important for human health. For instance, polyphenols are a large and diverse class of natural compounds found in fruit and known for their beneficial antioxidant, antimutagenic, anticarcinogenic and antiinflammatory properties (Duarte-Silva et al., 2000; Gupta et al., 2002; Franke et al., 2004). Polyphenols may also prevent diseases by improving genomic stability (De Flora et

Send correspondence to Ana Amélia de C. Melo-Cavalcante. Laboratório de Genética Toxicológica, Departamento de Biologia, Universidade Federal do Piauí, Campus Universitário Ministro Petrônio Portella, 64.049-550 Teresina, PI, Brazil. E-mail: ana ameliamelo@ibest.com.br. al., 2001; Ferguson, 2001). However, some of these compounds have mutagenic and pro-oxidant effects (Ferguson, 2001). There is limited conclusive data regarding the effects of complex mixtures, such as fruit juices and plant extracts, on genomic stability, but it is important to study them since these are the predominant forms in which fruit is consumed by humans.

The cashew tree (Anacardium occidentale Sapindales, Anacardiaceae), a tropical plant native to Brazil, produces a pseudo-fruit called the cashew apple that is commonly consumed in the northeastern Brazil as fresh cashew apple juice (CAJ) or as the processed juice (cajuina in Portuguese). Studies on the biological activities of these juices have shown that not only do they exhibit antibacterial, antifungal and antitumor activities (Kubo et al., 1993a; Kubo et al., 1993b) but also have antioxidant, antimutagenic and mutagenic properties against hydrogen peroxide (Melo-Cavalcante et al., 2003) and aflatoxins $\mathrm{B}_{1}$ (MeloCavalcante et al., 2005), mainly due to the high concentra- 
tions of anacardic acid, ascorbic acid, carotenoids and phenolic compounds found in the juices.

Methyl methanesulfonate (MMS) is a monofunctional alkylating agent which can induce gene mutation, unscheduled DNA synthesis and sister chromatid exchange, as well as other genotoxic effects (Eder et al., 2001; Sekihashi et al., 2001). The direct mutagen 4-nitroquinoline$\mathrm{N}$-oxide (4-NQO), which binds covalently to DNA, has also been widely used in studies of mutagenesis and carcinogenesis. In fact, 4-NQO is an oxidative mutagen that undergoes redox recycling to generate superoxide radical and other reactive oxygen species (Nunoshita and Demple, 1993; Pungartnik et al., 1999; Pungartnik et al., 2002). Both of these adducts can induce misreplication events which result in mutations (Nagao and Sugimura, 1976; Daubersies et al., 1992; Fronza et al., 1992). Benzo[a]pyrene $\mathrm{BaP}$ is a polycyclic aromatic hydrocarbon widely distributed in the environment (Hattemer-Frey and Travis, 1991). It is an indirect-acting mutagen that exhibits biological effects after its metabolic activation by P450-dependent monooxygenase enzymes, thus producing electrophilic species capable of reacting with nucleophilic sites of DNA to form adducts (Shoker et al., 2001; Jemnitz et al., 2004). It may induce both in vitro and in vivo gene mutations and chromosomal aberrations (Waters et al., 1991; Schoket et $a l ., 2001$ ) as well as DNA single-strand breaks (Garry et al., 2003).

During the study described in the present paper we investigate the antimutagenic properties of fresh unprocessed (CAJ) and processed (Cajuína) using the Salmonellal microsome assay and MMS and 4-NQO as direct mutagens and $\mathrm{BaP}$ as a metabolically activated mutagen.

\section{Materials and Methods}

\section{Preparation of fresh and processed CAJ}

The juices were produced using cashew apples from Piauí state in northeastern Brazil, the fruit having been bought in an open-air market in the town of Teresina and transported to our laboratory in a refrigerated container. During transport the fruits were kept in thermally insulated containers at $5{ }^{\circ} \mathrm{C}$. Visual inspection showed that all the fruits were in good condition, with no bruising, discoloration or obvious infection by fungi or bacteria. We obtained cashew apples which were pesticide-free and organically cultivated to general ones regarding antimutagenic activities. To produce fresh unprocessed juice the cashew apples were washed, surface sterilized in $70 \%(\mathrm{w} / \mathrm{v})$ ethanol for about five seconds followed by flaming, macerated and the juice sieved using sterile equipment. The fresh juice was frozen at $-20{ }^{\circ} \mathrm{C}$ until needed. Before freezing, a sample of the juice was tested for microorganisms by using standard microbiological tests for bacteria and fungi (Thatcher and Clark, 1972). Processed juice (cajuina) was produced from the fresh juice according to a commercial process (Lili
Doces (Lili Sweets), Teresina, Piauí) which, in addition to the steps described above, included centrifugation, clarification with gelatin, filtration and heating at $100{ }^{\circ} \mathrm{C}$ for $1 \mathrm{~h}$ (Melo-Cavalcante et al., 2003).

\section{Antimutagenicity assay}

We assessed the antimutagenicity capability of the fresh and the processed CAJ using the Salmonella typhimurium/microsome assay with the methodological variations described by Melo-Cavalcante et al. (2003).The Salmonella typhimurium test strains used were TA100 (his G46, bio chlD uvrB gal, rfa, pKM101), TA102 (his G428, rfa, pKM101, pAQ1) and TA97a (his 01242, bio chlD uvrB gal, rfa, pKM101) described by Maron and Ames (1983) and were kindly supplied by Dr. B.N. Ames, University of California, Berkeley, USA. The Moltox microsomal S9 fraction, prepared from the livers of Sprague-Dawley rats treated with the polychlorinated biphenyl mixture Aroclor 1254, was purchased from a commercial company (Molecular Toxicology Inc., USA) and the S9 metabolic activation mixture was prepared according to Mortelmans and Zeiger (2000). The standard mutagens MMS, BaP and 4-NQO were dissolved in dimethyl sulfoxide, all of which were purchased from Sigma. For the antimutagenicity assay, separate overnight cultures of $S$. typhimurium strains TA100, TA102 and TA97a were washed and resuspended in $5 \mathrm{~mL}$ of $0.2 \mathrm{M}$ phosphate buffered saline solution PBS $(\mathrm{pH} 7.4)$ to produce suspensions containing between $1 \times 10^{9}$ and $2 \times 10^{9}$ cells $\mathrm{mL}^{-1}$. The strains were chosen according to their sensitivity to mutagens with strains TA100 and TA102 being used, separately, in conjunction with $2 \mu \mathrm{g}$ plate $^{-1}$ of MMS plus $500 \mu \mathrm{L}$ per plate of the S9 mix while strain TA97a was used with $0.5 \mu \mathrm{g}$ plate $\mathrm{e}^{-1}$ of 4-NQO without the S9 mix and, in a separate assay, with $1 \mu \mathrm{g}$ plate ${ }^{-1}$ of BaP plus $500 \mu \mathrm{L}$ per plate of the S9 mix. Doses of fresh juice $\left(10 \mu \mathrm{L}, 25 \mu \mathrm{L}\right.$ and $50 \mu \mathrm{L}$ plate $\left.^{-1}\right)$ and processed juice $(100 \mu \mathrm{L}, 500 \mu \mathrm{L}$ and $2000 \mu \mathrm{L}$ per plate) were arbitrarily selected in preliminary assays designed to ascertain the dose range using a 20 min pre-incubation procedure at $37{ }^{\circ} \mathrm{C}$ with the addition of $100 \mu \mathrm{L}$ plate ${ }^{-1}$ of the appropriate bacterial strain with and without $500 \mu \mathrm{L}_{\text {plate }}{ }^{-1}$ of the $\mathrm{S} 9$ mix. The final criterion used to select the doses of fresh juice was non-toxicity. The following controls were used: for mutagen, $\mathrm{H}_{2} \mathrm{O}+$ mutagen + bacteria $\pm \mathrm{S} 9$ mix; for juice, $\mathrm{H}_{2} \mathrm{O}+$ juice + bacteria $\pm \mathrm{S} 9$ mix; for $\mathrm{S} 9$ mix, juice + bacteria + mutagen, with omission of S9 fractions; and for bacteria, $\mathrm{H}_{2} \mathrm{O}+$ bacteria $\pm \mathrm{S} 9$ mix.

The antimutagenicity of each dose of fresh or processed juice against mutagen was calculated as follows: percentage of inhibition $(\mathrm{PI} \%)=[1-(\mathrm{B}-\mathrm{A} / \mathrm{B})] \times 100$, where $\mathrm{A}$ represents the number of revertants plate ${ }^{-1}$ containing the mutagen and $\mathrm{B}$ represents the number of revertants plate $e^{-1}$ containing the mutagen plus fresh or processed juice. The number of spontaneous revertants was 
subtracted from all plates. The antimutagenic effect of the juices at non-toxic doses was given as the fifty-percent inhibitory dose $\left(\mathrm{ID}_{50}\right)$, i.e., the dose of juice producing a $50 \%$ reduction of mutagenicity in the test system. The result "indication of toxicity" was given when the number of his ${ }^{+}$ revertant colonies on plates with juice and mutagen was less than $70 \%$ in relation to the number of spontaneous revertants (negative control). Co-mutagenic activities were considered when the number of revertants on the plates with juices and mutagen was higher than that containing mutagen only. Data were expressed as means and standard deviation and statistically analyzed using one-way analysis of variance (ANOVA) followed by Dunnett's test. Differences between each juice treatment and its positive mutagenic control were considered significant at $* \mathrm{p} \leq 0.05$ and $* * \mathrm{p} \leq 0.01$.

\section{Results and Discussion}

The fresh juice showed up to $100 \%$ antimutagenic potential against MMS for strains TA100 and TA102, but only for the pre-treatment protocol (Table 1). Dose-dependence relationship did not occur, possibly because the three doses of fresh juice reached their maximum potential as either antimutagens or co-mutagens and, therefore, in most cases a significant difference was not observed between the three doses. In the pre-treatment protocol the cells were grown for $4 \mathrm{~h}$ in a nutrient medium with juice, allowing functional components from the fresh juice, such as ana-

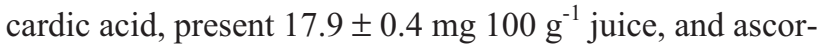

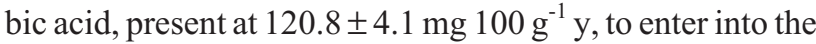
cells (data from Melo-Cavalcante et al., 2003). These chemicals may have contributed to the antimutagenic effect by increasing the defense against MMS in the pre-treatment due to the induction of protective adaptive systems. Oxidative stress-inducing agents up-regulate DNA polymerase beta and base excision repair (BER), increasing the resistance to alkylating agents such as MMS (Chen et al., 2001; Halliwell, 2001; Cabelof et al., 2002). Another possible mechanism is the protection against MMS by reducing the capacity of this chemical to alkylate DNA. Ascorbic acid may compete with DNA as a target for alkylation, reducing the genotoxicity of alkylating agents (Vijayalaxmi and Venu, 1999). The processed juice, conversely, showed an indication of toxicity in strain TA100 and MMS co-mutagenicity in strain TA102 when the pre-treatment protocol was applied (Table 1). Although the same basic components occur in both the fresh and processed juices (MeloCavalcante et al., 2003) we used higher concentrations of the processed juice, which may have elicited pro-oxidative effects from its components.

When the both types of juice were incubated with MMS under the co-incubation protocol for 20 min without washing before the addition of bacteria in co-treatment $\mathrm{A}$, potential induction of MMS mutagenicity was observed
(Table 1). In this case, possibly, there was insufficient time in this treatment for the induction of protection adaptive systems against MMS by the components of the juices, and/or extracellular reactions may have increased the formation of reactive agents to DNA.

In the post-treatment protocol involving strains TA100 and TA102 both juices produced an indication of toxicity, suggesting that the damage produced by MMS was not repaired by the juices and, in fact, the damage led to cell death (data not shown). It is known that DNA alkylation by monofunctional alkylating agents induces errorprone repair in bacteria, which can induce lethal mutations (Eder et al., 2001).

With 4-NQO, the juices showed antimutagenic activities in the TA97a pre-treatment (Table 2), 4-NQO being a well-known mutagen that undergoes redox recycling to generate the superoxide radical and other reactive species (Nunoshita and Demple, 1993; Brendel et al., 2003) which may be scavenged by antioxidant components of the juices such as phenols and anacardic acid (Melo-Cavalcante et al., 2003; Trevisan et al., 2006). Similar effects were also observed in strain TA97a during co-treatment A, with the antimutagenic potential reaching $99 \%$ (Table 2). In this system, antimutagenicity increased with the dose during both pre-treatment and co-treatments, but decreased in the post-treatment with fresh juice. There was no correlation between dose and effect in the treatments with processed juice (Table 2). The differences observed were related to the changes in the experimental procedure characterizing each treatment protocol (see above).

Both juices also showed post-treatment antimutagenic activities against 4-NQO in strain TA97a (Table 2), suggesting the presence of chemical compounds with effects on DNA repair against damage induced by 4-NQO. Several phenolic compounds, including tannic acid, present in both the fresh and processed juices have a role in the regulation of DNA-repair enzymes, reducing the yield of mutations (Cooke et al., 1998). In addition, by scavenging reactive species the antioxidant chemicals in the juices may have protected the TA97a cells against oxidative damage induced by 4-NQO.

Under most treatment protocols both juices showed antimutagenic responses in TA97a against the indirect mutagen $\mathrm{BaP}$ (Table 3 ). The processed juice showed an antimutagenic potential of approximately $100 \%$ and no comutagenic response, while the fresh juice was a potent antimutagenic agent in co-treatments $\mathrm{A}$ and $\mathrm{B}$ and in posttreatment and showed a co-mutagenic effect only in during pre-treatment (Table 3). It is known that $\mathrm{BaP}$ exhibits its biological effects after metabolic activation by P450-dependent monooxygenase enzymes to produce electrophilic species capable of reacting with nucleophilic sites of DNA to form adducts (Schoker et al., 2001; Hiramatsu et al., 2004; Kim et al., 2005). The components of the juices probably interacted with the active metabolites of $\mathrm{BaP}$ gener- 
Table 1 - Effects of cashew apple juice (CAJ) against methyl methanesulfonate (MMS) using Salmonella typhimurium strains TA100 and TA102 as indicator organisms. Percentage inhibition (PI) calculated as PI $=[1-(\mathrm{B}-\mathrm{A} / \mathrm{B})] \mathrm{X} 100$, where A represents plates containing mutagens and B represents the plate containing mutagens and juice. Antimutagenicity $=\mathrm{PI} \geq 50 \%$. Indication of toxicity when the number of revertant colonies $<70 \%$ compared to number of spontaneous revertants. Co-mutagenicity when there is a significant increase in mutagenicity as compared to positive control. The number of spontaneous revertants was subtracted from all plates. Values are means \pm standard deviations (SD). Protocols for CAJ testing: pre-treatment, juice + bacteria in fresh nutrient broth for $4 \mathrm{~h}$, wash bacteria and add mutagen for $20 \mathrm{~min}$, wash bacteria and plate; co-treatment A, juice + mutagen for 20 min, add to the bacteria and plate; and post-treatment A, bacteria + mutagen for 20 min, wash bacteria, add the juice and plate.

\begin{tabular}{|c|c|c|c|c|c|c|c|c|c|}
\hline \multirow[b]{3}{*}{$\begin{array}{l}\text { Protocols and CAJ } \\
\text { dose }\left(\mu \mathrm{L} \text { plate }^{-1}\right)\end{array}$} & \multicolumn{4}{|c|}{ Fresh juice } & \multicolumn{5}{|c|}{ Processed juice } \\
\hline & \multicolumn{4}{|c|}{$\begin{array}{c}\text { Number of } h i s^{+} \text {revertant colonies plate }{ }^{-1} \\
\quad(\text { Mean } \pm \text { SD for three replicates })\end{array}$} & \multirow[b]{2}{*}{$\begin{array}{l}\text { Procedure and CAJ } \\
\text { dose }\left(\mu \mathrm{L} \text { plate }^{-1}\right)\end{array}$} & \multicolumn{4}{|c|}{$\begin{array}{c}\text { Number of } h i s^{+} \text {revertant colonies plate }{ }^{-1} \\
\text { (Mean } \pm \text { SD for three replicates) }\end{array}$} \\
\hline & $\begin{array}{l}\text { Strain } \\
\text { TA100 }\end{array}$ & PI & $\begin{array}{l}\text { Strain } \\
\text { TA102 }\end{array}$ & PI & & $\begin{array}{l}\text { Strain } \\
\text { TA100 }\end{array}$ & PI & $\begin{array}{l}\text { Strain } \\
\text { TA102 }\end{array}$ & PI \\
\hline Pre-treatment & & & & & Pre-treatment & & & & \\
\hline 10 & $987 \pm 7^{*}$ & 67 & $202 \pm 3 *$ & 100 & 100 & $220 \pm 1^{*}$ & - & $2500 \pm 300 * *$ & - \\
\hline 25 & $645 \pm 9^{*}$ & 77 & $234 \pm 18^{*}$ & 86 & 500 & $63 \pm 0.1^{*}$ & - & $2381 \pm 300^{* *}$ & - \\
\hline 50 & $922 \pm 9^{*}$ & 64 & $213 \pm 4^{*}$ & 96 & 2000 & $0 \pm 0$ & - & $2200 \pm 102 * *$ & - \\
\hline Response & Antimut & & Antimu & & Response & Indic & & Co-mut & \\
\hline Co-treatment & & & & & Co-treatment & & & & \\
\hline 10 & $2113 \pm 63^{*}$ & - & $2437 \pm 283^{*}$ & - & 100 & - & & $2200 \pm 69^{* *}$ & - \\
\hline 25 & $1798 \pm 119^{*}$ & - & $2274 \pm 138^{*}$ & - & 500 & $392 \pm 4 *$ & & $2500 \pm 170^{* *}$ & - \\
\hline 50 & $2499 \pm 137^{*}$ & - & $2456 \pm 86^{*}$ & - & 2000 & $2500 \pm 400^{*}$ & & $2500 \pm 200 * *$ & - \\
\hline Response & Co-mut & & Co-mut & & Response & Co-mut & & Co-mut & \\
\hline Post-treatment A & & & & & Post-treatment A & & & & \\
\hline 10 & $0 \pm 0$ & - & $0 \pm 0$ & - & 100 & $52 \pm 1^{*}$ & - & $0 \pm 0$ & - \\
\hline 25 & $0 \pm 0$ & - & $0 \pm 0$ & - & 500 & $53 \pm 9^{*}$ & - & $0 \pm 0$ & - \\
\hline 50 & $0 \pm 0$ & - & $0 \pm 0$ & - & 2000 & $39 \pm 1$ & - & $0 \pm 0$ & - \\
\hline Response & Indic & & Indic & & Indic & Indic & & Indic & \\
\hline MMS $2 \mu$ g plate $^{-1}$ & $2257 \pm 511$ & - & $430 \pm 1$ & - & MMS $2 \mu \mathrm{g}$ plate ${ }^{-1}$ & $2.316 \pm 516$ & & $720 \pm 1$ & - \\
\hline $\begin{array}{l}\text { Spontaneous } \\
\text { revertants }\end{array}$ & $170 \pm 16$ & - & $203 \pm 6$ & - & $\begin{array}{l}\text { Spontaneous } \\
\text { revertants }\end{array}$ & $232 \pm 18$ & - & $240 \pm 31$ & - \\
\hline Juice control & & & & & Juice control & & & & \\
\hline 10 & $218 \pm 25$ & - & $286 \pm 5$ & - & 100 & $235 \pm 3$ & - & $245 \pm 11$ & - \\
\hline 25 & $209 \pm 39$ & - & $276 \pm 10$ & - & 500 & $262 \pm 7$ & - & $302 \pm 12$ & - \\
\hline 50 & $290 \pm 34$ & - & $263 \pm 6$ & - & 2000 & $390 \pm 15$ & - & $307 \pm 28$ & - \\
\hline
\end{tabular}

Antimut $=$ Antimutagenicity. Co-mut $=$ Co-mutagenicity. Indic $=$ Indication of toxicity.

*Statistically significant compared to the MMS at ${ }^{*} \mathrm{p} \leq 0.05$ and ${ }^{* *} \mathrm{p}<0.01$ by one-way analysis of variance ANOVA followed Dunnett's Test. A dash (-) indicates data not available.

ated by the presence of the S9 mix, resulting in the formation of non-mutagenic compounds. It is known that phenolic compounds can form complexes with $\mathrm{BaP}$ and reduce its bioavailability (Chen and Yen, 1997; Mejía et al., 1999; Gupta et al., 2002). Furthermore, ascorbic acid may inhibit the metabolic activation of BaP (Cooke et al., 1998; Rauscher et al., 1998).

A similar pattern of responses was found in previous studies in which fresh and processed CAJ protected $S$. typhimurium strain TA102 against DNA damage induced by aflatoxin B1. The mechanism responsible for this pro- tection included the possible interaction with S9 enzymes, and the transformation of aflatoxin B1 and its mutagenic metabolites to non-mutagenic compounds (Melo-Cavalcante et al., 2005). The stimulation of repair and/or reversion of DNA damage may have been another antimutagenic mechanism of fresh and processed CAJ during post-treatment. This protection may be attributed to the presence in both juices of chemically-active components shown to be involved in the protection of DNA (MeloCavalcante et al., 2003; Melo-Cavalcante et al., 2005). However, fresh juice increased $\mathrm{BaP}$ mutagenicity in the 
Table 2 - Effects of cashew apple juice (CAJ) against 4-nitroquinoline N-oxide (4-NQO) using Salmonella typhimurium strain TA97a as indicator organism. Percentage inhibition (PI) calculated as $\mathrm{PI}=[1-(\mathrm{B}-\mathrm{A} / \mathrm{B})] \mathrm{X} 100$, where A represents plates containing mutagens and B represents the plate containing mutagens and juice (Melo-Cavalcante et al., 2003) Antimutagenicity $=\mathrm{PI} \geq 50 \%$. Indication of toxicity when the number of revertant colonies $<70 \%$ compared to number of spontaneous revertants. Co-mutagenicity when there is a significant increase in mutagenicity as compared to positive control. The number of spontaneous revertants was subtracted from all plates. Values are means \pm standard deviations (SD). Protocols for CAJ testing: pre-treatment, juice + bacteria in fresh nutrient broth for $4 \mathrm{~h}$, wash bacteria and add mutagen for $20 \mathrm{~min}$, wash bacteria and plate; co-treatment $\mathrm{A}$, juice + mutagen for $20 \mathrm{~min}$, add to the bacteria and plate; and post-treatment, bacteria + mutagen for $20 \mathrm{~min}$, wash bacteria, add the juice and plate.

\begin{tabular}{|c|c|c|c|c|c|}
\hline \multicolumn{3}{|c|}{ Fresh juice } & \multicolumn{3}{|c|}{ Processed juice } \\
\hline \multirow[b]{2}{*}{$\begin{array}{l}\text { Protocols and CAJ dose } \\
\left(\mu \mathrm{L} \text { plate }^{-1}\right)\end{array}$} & \multicolumn{2}{|c|}{$\begin{array}{l}\text { Number of } h_{i s}^{+} \text {revertant colonies plate }{ }^{-1} \\
\quad \text { (Mean } \pm \text { SD for three replicates) }\end{array}$} & \multirow[b]{2}{*}{$\begin{array}{l}\text { Procedure and CAJ dose } \\
\left(\mu \mathrm{L} \text { plate }{ }^{-1}\right)\end{array}$} & \multicolumn{2}{|c|}{$\begin{array}{c}\text { Number of } h i s^{+} \text {revertant colonies plate }{ }^{-1} \\
\text { (Mean } \pm \text { SD f or three replicates) }\end{array}$} \\
\hline & Strain TA97a & PI & & Strain TA97a & PI \\
\hline Pre-treatment & & & Pre-treatment & & \\
\hline 10 & $389 \pm 43^{*}$ & 60 & 100 & $250 \pm 86^{*}$ & 70 \\
\hline 25 & $346 \pm 69^{*}$ & 66 & 500 & $234 \pm 3 *$ & 82 \\
\hline 50 & $321 \pm 53 *$ & 70 & 2000 & $198 \pm 24$ & 76 \\
\hline Response & Antimutagenicity & & Response & Antimutagenicity & \\
\hline Co-treatment & & & Co-treatment & & \\
\hline 10 & $514 \pm 57^{*}$ & 43 & 100 & $322 \pm 67^{*}$ & 70 \\
\hline 25 & $397 \pm 26^{*}$ & 60 & 500 & $347 \pm 34^{*}$ & 66 \\
\hline 50 & $111 \pm 2 *$ & 99 & 2000 & $194 \pm 23^{*}$ & 87 \\
\hline Response & Antimutagenicity & & Response & Antimutagenicity & \\
\hline Post-treatment A & & & Post-treatment A & & \\
\hline 10 & $173 \pm 37^{*}$ & 90 & 100 & $177 \pm 3^{*}$ & - \\
\hline 25 & $265 \pm 96^{*}$ & 78 & 500 & $133 \pm 10^{*}$ & - \\
\hline 50 & $269 \pm 51^{*}$ & 77 & 2000 & - & - \\
\hline Response & Antimutagenicity & & Indication of toxicity & Antimutagenicity & \\
\hline 4-NQO $0.5 \mu \mathrm{g}_{\text {plate }}{ }^{-1}$ & $823 \pm 184$ & - & 4-NQO $0.5 \mu$ g plate $^{-1}$ & $823 \pm 184$ & - \\
\hline Spontaneous revertants & $104 \pm 18$ & - & Spontaneous revertants & $104 \pm 18$ & - \\
\hline Juice control & & & Juice control & & \\
\hline 10 & $74 \pm 7$ & - & 10 & $108 \pm 12$ & - \\
\hline 25 & $118 \pm 17$ & - & 25 & $104 \pm 8$ & - \\
\hline 50 & $124 \pm 23$ & - & 50 & $108 \pm 12$ & - \\
\hline
\end{tabular}

*Statistically significant compared to the 4-NQO at * $\mathrm{p} \leq 0.05$ by one-way analysis of variance ANOVA followed Dunnett's Test. A dash (-) indicates data not available. ANOVA followed Dunnett's Test. A dash (-) indicates data not available.

pre-treatment, suggesting a co-mutagenic effect (Table 3). Again, a similar response was reported in experiments involving aflatoxin $\mathrm{B}_{1}$ when fresh juice was tested using pre-treatment of strain TA102 (Melo-Cavalcante et al., 2005). Many known antimutagenic chemicals of juices may also act as co-mutagens after metabolic activation and, moreover, polyphenols can be mutagenic, depending on whether they are present before, during, or after exposure to the relevant mutagen (Ferguson, 2001; Kozubek et al., 2001; Geetha et al., 2005).

In conclusion, the results indicate that both fresh and processed CAJ may be useful for protection against direct and indirect mutagens. The antimutagenic activities of these juices may have been mediated by some or all of the following: the generation of scavenger reactive species in treatments with 4-NQO; the induction of adaptive systems in treatments with MMS; the enhancement of DNA repair in treatments with 4-NQO and BaP; the inhibition of metabolic activation in treatments with $\mathrm{BaP}$; and the interaction with mutagen or pro-mutagen in treatments with MMS and $\mathrm{BaP}$. Therefore, both fresh and processed cashew apple juice may not be merely a source of nutrients but also a complex mixture of chemical compounds with beneficial properties for improving genomic stability. 
Table 3 - Effects of cashew apple juice (CAJ) against benzo[a]pyrene (BaP) using Salmonella typhimurium strain TA97a as indicator organism. Percentage inhibition $(\mathrm{PI})$ calculated as $\mathrm{PI}=[1-(\mathrm{B}-\mathrm{A} / \mathrm{B})] \mathrm{X} 100$, where A represents plates containing mutagens and $\mathrm{B}$ represents the plate containing mutagens and juice (Melo-Cavalcante et al., 2003) Antimutagenicity $=\mathrm{PI} \geq 50 \%$. Indication of toxicity when the number of revertant colonies $<70 \%$ compared to number of spontaneous revertants. Co-mutagenicity when there is a significant increase in mutagenicity as compared to positive control. The number of spontaneous revertants was subtracted from all plates. Values are means \pm standard deviations (SD). Protocols for CAJ testing: pre-treatment, juice + bacteria in fresh nutrient broth for $4 \mathrm{~h}$, wash bacteria and add mutagen $\pm \mathrm{S} 9 \mathrm{mix}$ for $20 \mathrm{~min}$, wash bacteria and plate; co-treatment, juice + mutagen for 20 min + S9 mix for $20 \mathrm{~min}$, add to the bacteria and plate, $(\operatorname{method} \mathrm{B})$ mutagen $+\mathrm{S} 9 \mathrm{mix}$ for $20 \mathrm{~min}$, add juice and incubate for $20 \mathrm{~min}$, add the bacteria and plate; post-treatment $\mathrm{A}$, bacteria + mutagen $+\mathrm{S} 9 \mathrm{mix}$ for $20 \mathrm{~min}$, wash bacteria, add the juice and plate; and post-treatment $\mathrm{B}$, bacteria + mutagen $+\mathrm{S} 9$ mix for $20 \mathrm{~min}$, wash and incubate with juice in fresh broth for $30 \mathrm{~min}$ wash bacteria and plate.

\begin{tabular}{|c|c|c|c|c|c|}
\hline \multicolumn{3}{|c|}{ Fresh juice } & \multicolumn{3}{|c|}{ Processed juice } \\
\hline \multirow[b]{2}{*}{$\begin{array}{l}\text { Protocols and CAJ dose } \\
\left(\mu \text { plate }^{-1}\right)\end{array}$} & \multicolumn{2}{|c|}{$\begin{array}{l}\text { Number of } h i s^{+} \text {revertant colonies plate }{ }^{-1} \\
\quad \text { (Mean } \pm \text { SD for three replicates) }\end{array}$} & \multirow[b]{2}{*}{$\begin{array}{l}\text { Procedure and CAJ dose } \\
\left(\mu \mathrm{L} \text { plate }^{-1}\right)\end{array}$} & \multicolumn{2}{|c|}{$\begin{array}{c}\text { Number of } \text { his }^{+} \text {revertant colonies plate } \\
\quad(\text { Mean } \pm \text { SD } \text { f or three replicates })\end{array}$} \\
\hline & Strain TA97 & PI & & Strain TA97 & PI \\
\hline Pre-treatment & & & Pre-treatment & & \\
\hline 10 & $770 \pm 94 *$ & & 100 & $222 \pm 5^{*}$ & 73 \\
\hline 25 & $1345 \pm 123^{*}$ & & 500 & $109 \pm 20^{*}$ & 99 \\
\hline 50 & $1350 \pm 147^{*}$ & & 2000 & $108 \pm 16^{*}$ & 99 \\
\hline Response & Co-mutagenicity & & Response & Antimutagenicity & \\
\hline Co-treatment & & & Co-treatment & & \\
\hline 10 & $411 \pm 82$ & 38 & 100 & $385 \pm 48^{*}$ & 62 \\
\hline 25 & $364 \pm 34^{*}$ & 50 & 500 & $514 \pm 16^{*}$ & 44 \\
\hline 50 & $365 \pm 19^{*}$ & 49 & 2000 & $286 \pm 59^{*}$ & 75 \\
\hline Response & Antimutagenicity & & Response & Antimutagenicity & \\
\hline Post-treatment A & & & Post-treatment A & & \\
\hline 10 & $399 \pm 22^{*}$ & 42 & 100 & $453 \pm 73^{*}$ & 53 \\
\hline 25 & $330 \pm 97 *$ & 57 & 500 & $295 \pm 40^{*}$ & 74 \\
\hline 50 & $278 \pm 61^{*}$ & 69 & 2000 & $395 \pm 55^{*}$ & 60 \\
\hline Response & Antimutagenicity & & Indication of toxicity & Antimutagenicity & \\
\hline Post-treatment B & & & Post-treatment B & & \\
\hline 10 & $251 \pm 73^{*}$ & 75 & 100 & $166 \pm 3^{*}$ & 80 \\
\hline 25 & $224 \pm 68$ & 81 & 500 & $141 \pm 50^{*}$ & 95 \\
\hline 50 & $303 \pm 75^{*}$ & 65 & 2000 & $208 \pm 22 *$ & 86 \\
\hline Response & Antimutagenicity & & Response & Antimutagenicity & \\
\hline $\mathrm{BaP} 1 \mu \mathrm{g}$ plate ${ }^{-1}$ & $583 \pm 129$ & - & $\mathrm{BaP} 1 \mu \mathrm{g}$ plate ${ }^{-1}$ & $837 \pm 63$ & - \\
\hline Spontaneous revertants & $141 \pm 26$ & - & Spontaneous revertants & $108 \pm 3$ & - \\
\hline \multicolumn{6}{|l|}{ S9 mix control } \\
\hline 10 & $138 \pm 12$ & & & $103 \pm 5$ & - \\
\hline 25 & $130 \pm 11$ & & & $173 \pm 5$ & - \\
\hline 50 & $298 \pm 36$ & & & $282 \pm 16$ & - \\
\hline Juice control & & & Juice control & & \\
\hline 10 & $145 \pm 9$ & - & 10 & $98 \pm 13$ & - \\
\hline 25 & $137 \pm 13$ & - & 25 & $192 \pm 13$ & - \\
\hline 50 & $128 \pm 17$ & - & 50 & $215 \pm 25$ & - \\
\hline
\end{tabular}

*Statistically significant compared to the BAP at *p $\leq 0.05$ by one-way analysis of variance ANOVA followed Dunnett's Test. A dash (-) indicates data not available. Followed Dunnett's Test. A dash (-) indicates data not available.

\section{Acknowledgments}

This work was supported by the following Brazilian organizations: the Federal University do Piauí (Genotoxi- city Laboratory); the Biotechnology Centre, Federal University of Rio Grande do Sul, (Laboratório de Genotoxicidade (GENOTOX), Centro de Biotecnologia, Universidade Federal do Rio Grande do Sul (UFRGS), Porto 
Alegre; the Brazilian National Counsel of Technological and Scientific Development (Conselho Nacional de Desenvolvimento Científico e Tecnológico, CNPq), and the Research foundation for the state of Rio Grande do Sul (Fundação de Amparo à Pesquisa do Estado do Rio Grande do Sul, FAPERGS)

\section{References}

Ames BN (2001) DNA damage from micronutrient deficiencies is likely to be a major cause of cancer. Mutat Res 475:7-2.

Brendel M, Bonatto D, Strauss M, Revers LF, Pungartnic C, Saffi J and Henriques JAP (2003) Role of PSO genes in repair of DNA damage of Saccharomyces cerevisiae. Mutat Res 544:179-193.

Cabelof DC, Raffoul JJ, Yanamadala S, Guo Z and Heydari AR (2002) Induction of DNA polymerase $\mu$ g-dependent base excision repair in response to oxidative stress in vivo. Carcinogenesis 23:1419-1425.

Cambie RC and Ferguson LR (2003) Potential functional food in the traditional Maori diet. Mutat Res. 523-524:109-117.

Chen HY and Yen GC (1997) Possible mechanism of antimutagens by various teas as judged by effects on mutagenesis by 2-amino-3 methylimidazol [4-5-7] quinoline and benzo[a]pyrene. Mutat Res 393:468-474.

Chen KH, Srivastava DK and Wilson SH (2001) Relationship between base excision repair capacity and DNA alkylating agent sensitivity in mouse monocytes. Mutat Res 487:121126.

Cooke MS, Evans MD, Podmore ID, Herbert KE, Mistry N, Mistry P, Hickenbotham PT, Hussieni A, Griffiths HR and Lunec J (1998) Novel repair action of vitamin C upon in vivo oxidative DNA damage. FEBS Lett 439:363-367.

Daubersies P, Galiegue-Zouitina S, Koffel-Schwartz N, Funchs RPP, Loucheux-Lefebvre M-H and Bailleul B (1992) Mutation spectra of the two guanine adducts of the carcinogen 4-nitroquinoline-1-oxide in Escherichia coli. Influence of neighbouring base sequence on mutagenesis. Carcinogenesis 13:349-354.

De Flora S, Izzotti A, D'Agostini F, Balansky RMD and Noonan AA (2001) Multiple points of intervention in the prevention of cancer and other mutation-related diseases. Mutat Res 480-48:9-22.

Duarte-Silva I, Gaspar J, Gomes da Costa G, Rodrigues AS, Laires A and Rueff J (2000) Chemical features of flavonols affecting their genotoxicity. Potential implications in their use as therapeutical agents. Chem-Biol Interact 124:29-51.

Eder E, Kütt W and Deininger C (2001) On the role of alkylating mechanisms, O-alkylation and DNA-repair in genotoxicity and mutagenicity of alkylating methanesulfonate of widely varying structures in bacterial systems. Chem-Biol Interact 137:89-99.

Ferguson LR (2001) Role of plant polyphenols in genomic stability. Mutat Res 475:89-111.

Franke SIR, Ckless K, Silveira JD, Rubensam G, Brendel M, Erdtmann B and Henriques JAP (2004) Study of antioxidant and mutagenic activity of different orange juices. Food Chem Toxicol 88:45-55.

Fronza G, Campomenosi P, Iannone R and Abbondandolo A (1992) The 4-nitroquinoline-1-oxide mutational spectrum in single-strand DNA is characterized by guanine to pyrimidine transversions. Nucleic Acids Res 20:1283-1287.

Garry S, Nesslany F, Aliouat E, Haquenoer J-M and Marzin D (2003) Assessment of genotoxic effect of benzo[a]pyrene in endotracheally treated rat using comet assay. Mutat Res 534:33-43.

Geetha T, Malhotra V, Chopra K and Kaur IP (2005). Antimutagenic and antioxidant activity of quercetin. Ind J Exp Biol 43:61-67.

Gupta S, Saha B and Giri AK (2002) Comparative antimutagenic and anticlastogenic effects of green tea and black tea: A review. Mutat Res 512:37-65.

Halliwell B (2001) Vitamin C and genomic stability. Mutat Res 475:29-35.

Hattemer-Frey HA and Travis CC (1991) Benzo[a]pyrene: Environmental partitioning and human exposure. Toxicol Ind Health 7:141-157.

Hiramatsu N, Xiufen W, Takechi R, Itoh Y, Mamo J and Pal S (2004) Antimutagenicity of Japanese traditional herbs, gennoshoko, yomogi, senburi and iwa-tobacco. Biofactors 22:123-125.

Jemnitz K, Veres Z, Torok G, Toth E and Vereczkey L (2004) Comparative study in the Ames test of benzo[a]pyrene and 2-aminoanthracene metabolic activation using rat hepatic S9 and hepatocytes following in vivo or in vitro situation. Mutagenesis 19:245-250.

Kim SR, Kokubo K, Matsui K, Yamada N, Kanke Y, Fukuoka M, Yamada M and Nohmi T (2005) Light-dependent mutagenesis by benzo[a]pyrene is mediated via oxidative DNA damage. Environ Mol Mutagen 46:141-149.

Kozubek A, Zarnowski R, Stasiuk M and Gubernator J (2001) Natural amphiphilic phenols as bioactive compounds. Cell Mol Biol Lett 6:351-355.

Kubo I, Muroi H and Himejima M (1993a) Structure-antibacterial activity relations of anacardic acids. J Agric Food Chem 41:1016-1019.

Kubo I, Ochi M, Vieira PC and Komatsu S (1993b) Antitumor agents from the cashew (Anacardium occidentale) apple juice. J Agric Food Chem 41:1012-1015.

Maron DM and Ames BN (1983) Revised methods for the Salmonella mutagenicity test. Mutat Res113:173-215.

Mejía EG, Castano TC and Loarca P (1999) Antimutagenic effects of natural phenolic compounds in beans. Mutat Res 441:1-9.

Melo-Cavalcante AAC, Rübensam G, Erdtmann B, Brendel M and Henriques JAP (2005) Cashew (Anacardium occidentale) apple juice lowers mutagenicity of aflatoxin B1 in S. typhimurium TA102. Genet Mol Biol 28:328-333.

Melo-Cavalcante AAC, Rübensam G, Picada JN, Silva EG, Moreira JCF and Henriques JAP (2003) Mutagenic evaluation, antioxidant potential and antimutagenic activity against hydrogen peroxide of cashew (Anacardium occidentale) apple juice and cajuina. Environ Mol Mutat 41:360-369.

Mortelmans K and Zeiger E (2000) The Ames Salmonella / microsome mutagenicity assay. Mutat Res 455:29-60.

Nagao M and Sugimura T (1976) Molecular biology of the carcinogen 4-nitroquinoline-1-oxide. Adv Cancer Res 23:132169. 
Nunoshita T and Demple B (1993) Potent intracellular oxidative stress exerted by the carcinogen 4-nitroquinoline- $\mathrm{N}$-oxide. Cancer Res 53:3250-3252.

Pungartnik C, Kern MF, Brendel M and Henriques JAP (1999) Mutant allele pso-7, that sensitizes Saccharomyces cerevisiae to photoactivated psoralen, is allelic with COX11, encoding a protein indispensable for a functional cytochrome c oxidase. Curr Genet 36:124-129.

Pungartnik C, Picada JN, Brendel M and Henriques JAP (2002) Further phenotypic characterization of pso mutants of Saccharomyces cerevisiae with respect to DNA repair and responsive to oxidative stress. Genet Mol Res 10:79-89.

Rauscher R, Edenharder R and Platt KL (1998) In vitro antimutagenic and in vivo anticlastogenic effects of carotenoids and solvent extracts from fruits and vegetables rich in carotenoids. Mutat Res 413:129-142.

Schoket B, Papp G, Lévay K, Mracková G, Kadlubar FF and Vincze I (2001) Impact of metabolic genotypes on levels of biomarkers of genotoxic exposure. Mutat Res 482:5769.
Sekihashi K, Sasaki T, Yamamoto A, Kawamura K, Ikka T, Tsuda S and Sasaki YF (2001) A comparison of intraperitoneal and oral gavage administration in comet assay in mouse eight organs. Mutat Res 493:39-54.

Thatcher FS and Clark DS (1972) Microrganisms in food. Canadá University Press, Torronto, $234 \mathrm{pp}$.

Trevisan MT, Pfundstein B, Haubner R, Wurtele G, Spiegelharder B, Bartsch H and Owen RW (2006) Characterization of alkyl phenols in cashew (Anacardium occidentale) products and assay of their antioxidant capacity. Food Chem Toxicol 44:188-197.

Vijayalaxmi KK and Venu R (1999) In vivo anticlastogenic effects of L-ascorbic acid in mice Mutat Res 438:47-51.

Waters MD, Stack HF, Garett NE and Jackson MA (1991) The genetic activity profile database. Environ Health Perspect 96:41-45.

Associate Editor: Catarina S. Takahashi

License information: This is an open-access article distributed under the terms of the Creative Commons Attribution License, which permits unrestricted use, distribution, and reproduction in any medium, provided the original work is properly cited. 